\title{
Inhibition of human and ovine acrosomal enzymes by tannic acid in vitro
}

\author{
I. A. Taitzoglou ${ }^{1}$, M. Tsantarliotou ${ }^{2}$, I. Zervos ${ }^{1}$, D. Kouretas ${ }^{3}$ \\ and N. A. Kokolis ${ }^{2 *}$ \\ ${ }^{1}$ Department of Physiology, Faculty of Veterinary Medicine, University of Thessaly, \\ 43100 Karditsa, Greece; ${ }^{2}$ Department of Physiology, Faculty of Veterinary Medicine, \\ Aristotle University, 54006 Thessaloniki, Greece; and ${ }^{3}$ Department of Physiology, \\ School of Agricultural Sciences, University of Thessaly, Pedion Areos, Volos, Greece
}

The effect of tannic acid, a common flavonoid, on the acrosin and plasminogen activator activity and plasmin activity of human and ram spermatozoa was evaluated. Acrosin and plasminogen activator activity were determined by spectrophotometry using the chromogenic substrates $\mathrm{N}$ - $\alpha$-benzoyl-DL-arginine para-nitroanilide- $\mathrm{HCl}$ (BAPNA) and H-D-valyl-L-leucyl-L-lysine-p-nitroanilide$2 \mathrm{HCl}$ (S-2251), respectively. In extracts from both human and ovine acrosomes, the activities of acrosin and plasminogen activators were susceptible to tannic acid inhibition. The inhibitory effect of tannic acid was observed at concentrations $>50 \mu \mathrm{mol} \mathrm{I}^{-1}$ in a dose-dependent manner. In additional experiments, low concentrations of tannic acid significantly inhibited tissue-type plasminogen activator, urokinase-type plasminogen activator and plasmin activity in a concentration-dependent manner over the range $0.25-200 \mu \mathrm{mol} \mathrm{I}^{-1}$. Tannic acid reduced the motility of ram spermatozoa at a concentration of $1000 \mu \mathrm{mol} \mathrm{I}^{-1}$ after 2 and $3 \mathrm{~h}$ co-incubation with spermatozoa. The motility of human spermatozoa remained unchanged over the range 0.1-1000 $\mu \mathrm{mol}$ tannic acid $\mathrm{I}^{-1}$ during $3 \mathrm{~h}$ co-incubation. These results indicate that tannic acid inhibited the activity of both acrosin and plasminogen activator and indicates a possible mechanism by which flavonoids exert their antifertility effects.

\section{Introduction}

Acrosomal enzymes appear to have an essential role in induction of the acrosome reaction, as well as in sperm binding to and penetration through the layers surrounding oocytes (Yanagimachi, 1994). The most widely studied acrosomal enzyme is the endoproteinase acrosin (EC 3.4.21.10). Acrosin is a sperm acrosomal serine proteinase that is involved in the early stages of fertilization: the acrosome reaction (Lui and Meizel, 1979; Tesarik et al., 1988; De Jonge et al., 1989), recognition and binding of spermatozoa to the zona pellucida (Saling, 1981; Jones, 1991; Urch and Patel, 1991) and penetration of the zona pellucida by spermatozoa (Kennedy et al., 1983; Schill, 1991).

Spermatozoa contain a number of other proteinases besides acrosin with less well-documented roles in reproduction. Plasminogen activators, as well as plasminogen activator inhibitors and plasmin inhibitors, have been found in ejaculated spermatozoa from various species (humans, bulls, rams, bucks, boars and stallions) (Smokovitis et al., 1987). There are at least two types of plasminogen

*Correspondence

Email: nkokolis@vet.auth.gr activators in mammals: the tissue-type plasminogen activator (t-PA) and the urokinase-type plasminogen activator $(\mathrm{u}-$ $\mathrm{PA})$, which convert the abundant extracellular zymogen plasminogen to plasmin. Plasmin is the active proteinase that stimulates fibrinolysis and proteolysis. The plasminogen activators and their inhibitors are localized to the outer acrosomal membrane and plasma membrane of human and boar spermatozoa (Smokovitis et al., 1992a). In addition, plasminogen activator activity varies with breed and season (Rekkas et al., 1993) and is influenced by chromosomal anomalies (Smokovitis et al., 1992b) and hormones (Rekkas et al., 1991; Tsantarliotou, 1997) in rams. During the acrosome reaction plasminogen activators are released in human, boar, bull and ram spermatozoa (Taitzoglou et al., 1996).

It has been estimated that humans consume approximately $1 \mathrm{~g}$ mixed flavonoids per day (Hertog et al., 1993). There is much evidence from human epidemiological and animal studies that there are beneficial effects associated with the consumption of polyphenols (Bravo, 1998; Chung et al., 1998). It has been demonstrated recently that polyphenols, such as flavonoids and their glycosides, are present in human plasma at concentrations between 0.5 and $1.6 \mathrm{~mol} \mathrm{I}^{-1}$ (Paganga and Rice-Evans, 1997). Tannins are plant polyphenols comprising a heterologous group of 
compounds. Tannic acid is a common flavonoid found in tea, coffee, red wine and immature fruits, and it has also been used as a food additive. Tannic acid is reported to have potent inhibitory effects on the activity of hyaluronidase extracted from cynomolgus monkey spermatozoa (Li et al., 1997). Another plant-derived polyphenolic compound, gossypol, has long been the focus of research efforts due to its antifertility effects in males (Shi and Friend, 1985; Srivastava et al., 1989). The results of a recent study indicated that gossypol has dose-dependent inhibitory effects on several rabbit acrosomal enzymes (Yuan et al., 1995). In addition, gossypol was found to inhibit the activities of human and ovine acrosomal plasminogen activators (Taitzoglou et al., 1999).

The aim of the present study was to determine the effects of tannic acid on the activities of acrosin and plasminogen activator extracted from human and ram spermatozoa and on pure t-PA, u-PA and plasmin preparations to elucidate further the role of acrosin and plasminogen activator and the plasmin system in fertilization.

\section{Materials and Methods}

\section{Chemicals}

The plasminogens used were isolated from human and ovine blood plasma by affinity chromatography on lysine-sepharose 4B (Sigma, Deisenhofen) as described by Deutsch and Mertz (1970). Tannic acid (molecular weight 1701.23) was obtained from Sigma; immediately before use it was dissolved in Tris- $\mathrm{HCl}$ buffer $\left(0.1 \mathrm{~mol} \mathrm{I}^{-1}\right.$; $\mathrm{pH}$ 7.4) to the appropriate concentration. The substrate for plasmin was H-D-valyl-L-leucyl-L-lysine-p-nitroanilide$2 \mathrm{HCl}$ (S-2251) (Chromogenix, Mölntal). Plasmin from pig blood (Sigma), two-chain t-PA (Biopool, Umeå) and purified human u-PA (Serono, Rome) were used for the inhibition assays and to draw the standard curves. All other chemicals were of the highest purity available.

\section{Assessment of sperm motility}

Before studying the effects of tannic acid on acrosin and plasminogen activator activity from human and ram spermatozoa, the effects of tannic acid on sperm motility were determined. In brief, washed semen samples were diluted with modified Biggers, Whitten and Whittingham (BWW) medium different for each species (Biggers et al., 1971; Taitzoglou et al., 1996) into $5 \mathrm{ml}$ plastic centrifuge tubes and incubated at $37^{\circ} \mathrm{C}$, in $5 \% \mathrm{CO}_{2}$ in air. The percentage motility of the spermatozoa was evaluated visually at $1 \mathrm{~h}$ intervals by placing a drop of each sperm suspension onto a prewarmed microscope slide with prewarmed coverslip and observing at $\times 200$ magnification with a temperaturecontrolled $\left(37^{\circ} \mathrm{C}\right)$ phase contrast microscope. At least four fields were evaluated and 200 spermatozoa were counted in each sample. The final concentrations of tannic acid were $0,0.1,1.0,10.0,100.0$ and $1000.0 \mu \mathrm{mol} \mathrm{I}^{-1}$.
Preparation of acrosomal extracts for plasminogen activator activity assay

Men. Semen was obtained from healthy donors $(n=5)$ with normal parameters of sperm density, motility and morphology (WHO, 1992). The samples were allowed to liquefy for $30 \mathrm{~min}$ at room temperature before processing. Seminal plasma was removed by layering semen over $11 \%$ Ficoll in $\mathrm{NaCl}\left(0.12 \mathrm{~mol} \mathrm{l}^{-1}\right)$ containing Hepes $\left(0.025 \mathrm{~mol} \mathrm{I}^{-1}\right), \mathrm{pH} 7.4$ and centrifuged at $1000 \mathrm{~g}$ for $10 \mathrm{~min}$ at room temperature (Kennedy et al., 1989). The seminal plasma and Ficoll supernatant were removed and the sperm pellet was resuspended in $1 \mathrm{ml}$ Tris- $\mathrm{HCl}\left(0.1 \mathrm{~mol} \mathrm{I}^{-1}\right)$, $\mathrm{pH} 7.4$ and centrifuged again at $500 \boldsymbol{g}$ for $2 \mathrm{~min}$. Finally, the sperm pellet was extracted with a mixture of 4 volumes of Tris- $\mathrm{HCl}\left(0.1 \mathrm{~mol} \mathrm{I}^{-1}\right)$ and 1 volume of potassium thiocyanate $\left(0.5 \mathrm{~mol} \mathrm{I}^{-1}\right), \mathrm{pH} 7.4$, to a concentration of $5 \times 10^{7}$ spermatozoa $\mathrm{ml}^{-1}$ (Smokovitis et al., 1987). The supernatants were collected and stored at $-70^{\circ} \mathrm{C}$ until assayed.

Rams. Ejaculates from Friesian rams $(n=10)$ (National Agricultural Research Foundation, Thessaloniki, Greece) were collected once a week using an artificial vagina. Any sample with $<60 \%$ motile spermatozoa was discarded. Pooled semen was centrifuged each time at $900 \mathrm{~g}$ for $15 \mathrm{~min}$ at $22^{\circ} \mathrm{C}$ to sediment the spermatozoa. The spermatozoa acrosomal extract was prepared as described by Srivastava (1973) and Srivastava et al. (1974). In brief, washed spermatozoa were stirred first with $\mathrm{MgCl}_{2}$ $\left(0.05 \mathrm{~mol} \mathrm{I}^{-1}\right)$ in Tris maleate $\left(0.05 \mathrm{~mol} \mathrm{I}^{-1}\right)$ buffer, $\mathrm{pH}$ 6.1, at $2-4^{\circ} \mathrm{C}$ for $30 \mathrm{~min}$ and centrifuged at $900 \mathrm{~g}$ for $15 \mathrm{~min}$. After the $\mathrm{MgCl}_{2}$ treatment the spermatozoa were incubated with $0.1 \%(\mathrm{v} / \mathrm{v})$ hyamine 2389 and $0.1 \%(\mathrm{v} / \mathrm{v})$ Triton X-100 in Tris-maleate buffer and the detergent extracts were precipitated with three volumes of ethanol $\left(-15^{\circ} \mathrm{C}\right)$ dialysed against glass distilled water and stored at $-70^{\circ} \mathrm{C}$ until assayed.

\section{Plasminogen activator activity assay}

Plasminogen activator activity was determined by spectrophotometry using the chromogenic substrate S-2251 (H-D-valyl-L-leucyl-L-lysine-p-nitroanilide-2HCl) as described in detail by Smokovitis et al. (1987). In brief, a total volume of $500 \mu \mathrm{l}$ mixture consisting of $200 \mu \mathrm{l}$ substrate S-2251 (final concentration $0.73 \mathrm{mmol} \mathrm{I}^{-1}$ ), $100 \mu \mathrm{l}$ plasminogen solution (final concentration 0.5 casein units $\left.\mathrm{ml}^{-1}\right), 100 \mu \mathrm{l}$ Tris- $\mathrm{HCl}$ buffer $\left(0.1 \mathrm{~mol} \mathrm{I}^{-1}\right), \mathrm{pH} 7.4$, and $100 \mu \mathrm{l}$ acrosomal extract was incubated for $30 \mathrm{~min}$ at $37^{\circ} \mathrm{C}$. The reaction was terminated by adding $1000 \mu \mathrm{l} \mathrm{50 \%}$ $(\mathrm{v} / \mathrm{v})$ acetic acid. The absorbance was read at $405 \mathrm{~nm}$.

In separate experiments, plasminogen activator activity and plasmin activity were evaluated in pure enzyme preparations. For this purpose, the $100 \mu \mathrm{l}$ acrosomal extract used in the plasminogen activator activity assay was substituted with $100 \mu$ l of a solution containing 5 iu t-PA, 50 miu u-PA or $20 \mu \mathrm{l}$ of a solution containing 2 miu plasmin. No plasminogen was added for determination of plasmin activity. 
Plasminogen activator activity and plasmin activity were expressed in terms of t-PA (iu), u-PA (miu) and plasmin (miu) by referring the net absorbance to standard curves which were drawn using 1-50 iu t-PA, 10-500 miu u-PA or 0.5-10 miu plasmin, respectively.

\section{Acrosin assay}

Acrosin activity was determined in human and ram spermatozoa by spectrophotometry (Kennedy et al., 1989) using the chromogenic substrate BAPNA ( $N$ - $\alpha$-benzoyl-DLarginine para-nitroanilide- $\mathrm{HCl}$; Sigma). In brief, a small volume of each ejaculate was washed with Ficoll solution; human spermatozoa were washed twice. After washing, a $100 \mu$ l volume $\left(0.12 \mathrm{~mol} \mathrm{NaCl} \mathrm{I}^{-1}, 0.025 \mathrm{~mol}\right.$ Hepes $\mathrm{I}^{-1}$, $\mathrm{pH}$ 7.4) containing $5.0 \times 10^{6}$ human spermatozoa or $5.0 \times 10^{5}$ ram spermatozoa was obtained from each sample; $100 \mu$ l benzamidine (Sigma) solution $\left(0.5 \mathrm{~mol} \mathrm{I}^{-1}\right)$ was added to control tubes and $1 \mathrm{ml}$ BAPNA solution was added to all tubes after vortexing. The chromogenic substrate solution was prepared by dissolving BAPNA in dimethylsulphoxide (DMSO) to a final concentration of $23 \mathrm{mmol} \mathrm{I}^{-1}$. The BAPNA-DMSO solution was diluted nine times with an extender $(0.01 \%(\mathrm{v} / \mathrm{v})$ Triton $\mathrm{X}-100$ in 0.055 mol Hepes $\mathrm{I}^{-1}, 0.055 \mathrm{~mol} \mathrm{NaCl}{ }^{-1}$ (pH 8.0). The tubes were incubated at $37^{\circ} \mathrm{C}$ for 90 min (Mack and Zaneveld, 1987). After incubation, $100 \mu$ l benzamidine solution was added to the test tubes and all the tubes were centrifuged at $1000 \boldsymbol{g}$ for $15 \mathrm{~min}$. The supernatants were collected and the absorbance was read at $410 \mathrm{~nm}$. The difference between control and test tubes was adopted as the net absorbance. Acrosin activity was expressed as $\mu \mathrm{iu} 10^{-6}$ spermatozoa.

\section{Studies of inhibition}

Enzyme inhibition studies were performed by preincubating a range of tannic acid concentrations with samples at $37^{\circ} \mathrm{C}$ for $10 \mathrm{~min}$. Each experiment was repeated at least five times. Incubations were run in duplicate.

\section{Statistical analysis}

Statistical analysis was performed by Student's $t$ test. The level of significance was $P<0.05$.

\section{Results}

\section{Effect of tannic acid on sperm motility}

Before examining the effect of tannic acid on sperm acrosomal enzymes it was necessary to determine the effect of this compound on sperm motility. Sperm motility was examined at $1 \mathrm{~h}$ intervals during $3 \mathrm{~h}$ co-incubation with tannic acid. It was found that 0.1-1000 $\mu$ mol tannic acid $\mathrm{I}^{-1}$ did not affect the motility of human spermatozoa, whereas $1000 \mu \mathrm{mol}$ tannic acid $\mathrm{I}^{-1}$ significantly inhibited the motility of ram spermatozoa after 2 and $3 \mathrm{~h}$ incubation (Table 1).

\section{Effect of tannic acid on acrosomal plasminogen activator activity}

The plasminogen activator activity of both human and ovine acrosomal extracts was susceptible to tannic acid inhibition. The inhibitory effect of tannic acid was observed

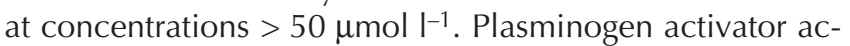
tivity decreased in a concentration-dependent manner: a $50 \%$ reduction $\left(\mathrm{IC}_{50}\right)$ in the plasminogen activator activity of human and ovine extracts occurred at 100 and $200 \mu$ mol tannic acid $\mathrm{I}^{-1}$, respectively. Plasminogen activator activity in human extracts (38 iu t-PA $10^{-8}$ spermatozoa) and in ovine extracts (1588 iu t-PA $10^{-8}$ spermatozoa) was inhibited almost completely by tannic acid at concentrations of 500 and $700 \mu \mathrm{mol} \mathrm{I-1}$, respectively (Table 2).

\section{Effect of tannic acid on acrosin activity}

Tannic acid inhibited acrosin activity in both human and ovine acrosomal extracts, at concentrations as low as $50 \mu \mathrm{mol} \mathrm{I}^{-1}$ (Table 3). The sensitivity of acrosin to inhibition by tannic acid was highest at 50-400 $\mu \mathrm{mol}$ tannic

Table 1. Percentage motility of human and ovine spermatozoa after $0,1,2$ and $3 \mathrm{~h}$ incubation with tannic acid

\begin{tabular}{|c|c|c|c|c|c|c|c|c|}
\hline \multirow{3}{*}{$\begin{array}{l}\text { Tannic } \\
\text { acid } \\
\left(\mu \mathrm{mol} \mathrm{I}^{-1}\right)\end{array}$} & \multicolumn{4}{|c|}{ Human spermatozoa } & \multicolumn{4}{|c|}{ Ovine spermatozoa } \\
\hline & \multicolumn{4}{|c|}{ Duration of incubation (h) } & \multicolumn{4}{|c|}{ Duration of incubation (h) } \\
\hline & 0 & 1 & 2 & 3 & 0 & 1 & 2 & 3 \\
\hline 0 & $81.25 \pm 4.15$ & $71.25 \pm 6.50$ & $66.25 \pm 6.50$ & $61.25 \pm 4.15$ & $77.50 \pm 4.33$ & $70.00 \pm 3.54$ & $63.75 \pm 2.17$ & $63.75 \pm 4.15$ \\
\hline 0.1 & $78.75 \pm 2.15$ & $70.00 \pm 6.12$ & $65.00 \pm 3.54$ & $60.00 \pm 6.12$ & $76.25 \pm 4.14$ & $70.00 \pm 6.12$ & $62.50 \pm 2.50$ & $63.75 \pm 2.17$ \\
\hline 1 & $78.75 \pm 2.15$ & $68.75 \pm 5.45$ & $65.00 \pm 6.12$ & $60.00 \pm 7.08$ & $76.25 \pm 6.50$ & $68.75 \pm 2.17$ & $61.25 \pm 4.15$ & $61.25 \pm 5.45$ \\
\hline 10 & $77.50 \pm 2.50$ & $67.50 \pm 5.59$ & $65.00 \pm 7.90$ & $57.50 \pm 8.29$ & $75.00 \pm 6.12$ & $66.25 \pm 4.15$ & $61.25 \pm 2.17$ & $58.75 \pm 2.17$ \\
\hline 100 & $77.50 \pm 4.33$ & $65.00 \pm 3.54$ & $63.75 \pm 6.50$ & $56.25 \pm 5.45$ & $75.00 \pm 5.00$ & $66.25 \pm 2.16$ & $60.00 \pm 3.54$ & $57.50 \pm 4.33$ \\
\hline 1000 & $75.00 \pm 6.12$ & $63.75 \pm 4.15$ & $62.50 \pm 4.33$ & $55.00 \pm 6.12$ & $73.75 \pm 5.45$ & $65.00 \pm 3.54$ & $43.75 \pm 2.17^{a}$ & $22.50 \pm 2.50^{\mathrm{a}}$ \\
\hline
\end{tabular}

Values are mean percentage motility $\pm \mathrm{SD}(n=4)$.

aValues with a superscript are significantly different from the other values within that column $(P<0.001)$. 
Table 2. Inhibitory effects of tannic acid on the activity of tissue-type plasminogen activator extracted from human and ram spermatozoa

\begin{tabular}{|c|c|c|c|c|}
\hline \multirow[b]{2}{*}{$\begin{array}{l}\text { Tannic acid } \\
\left(\mu \mathrm{mol} \mathrm{I}^{-1}\right)\end{array}$} & \multicolumn{2}{|c|}{ Human } & \multicolumn{2}{|c|}{ Ram } \\
\hline & $\begin{array}{l}\text { Residual activity } \\
(\%)\end{array}$ & $\begin{array}{l}\text { Tissue-type } \\
\text { plasminogen activator } \\
\text { (iu } 10^{-8} \text { spermatozoa) }\end{array}$ & $\begin{array}{c}\text { Residual activity } \\
(\%)\end{array}$ & $\begin{array}{c}\text { Tissue-type } \\
\text { plasminogen activator } \\
\text { (iu } 10^{-8} \text { spermatozoa) }\end{array}$ \\
\hline 0 & 100 & $38.00 \pm 2.74$ & 100 & $1588.00 \pm 63.21$ \\
\hline 50 & $77.40 \pm 7.02^{\mathrm{a}}$ & $29.41 \pm 2.67^{a}$ & $85.50 \pm 4.70^{a}$ & $1356.15 \pm 74.14^{\mathrm{a}}$ \\
\hline 100 & $52.80 \pm 6.80^{\mathrm{a}}$ & $20.06 \pm 2.58^{\mathrm{a}}$ & $63.40 \pm 6.27^{a}$ & $1006.79 \pm 99.55^{a}$ \\
\hline 200 & $35.60 \pm 7.23^{a}$ & $13.53 \pm 2.75^{\mathrm{a}}$ & $48.20 \pm 5.26^{\mathrm{a}}$ & $765.42 \pm 83.58^{a}$ \\
\hline 300 & $21.60 \pm 5.99^{a}$ & $8.21 \pm 2.16^{\mathrm{a}}$ & $38.80 \pm 4.35^{\mathrm{a}}$ & $616.14 \pm 68.67^{a}$ \\
\hline 400 & $14.00 \pm 3.54^{\mathrm{a}}$ & $5.32 \pm 1.34^{\mathrm{a}}$ & $29.80 \pm 3.35^{\mathrm{a}}$ & $473.22 \pm 53.14^{a}$ \\
\hline 500 & $5.20 \pm 1.64^{\mathrm{a}}$ & $1.98 \pm 0.62^{\mathrm{a}}$ & $24.60 \pm 2.70^{\mathrm{a}}$ & $390.65 \pm 42.90^{\mathrm{a}}$ \\
\hline 600 & - & - & $20.20 \pm 1.92^{a}$ & $320.78 \pm 30.55^{a}$ \\
\hline 700 & - & - & $9.20 \pm 1.52^{\mathrm{a}}$ & $152.45 \pm 24.08^{\mathrm{a}}$ \\
\hline
\end{tabular}

-: total inhibition.

Values are mean $\pm \mathrm{SD}(n=5)$.

aValues with a superscript are significantly different from control value within each column $(P \leqslant 0.05)$.

Table 3. Inhibitory effects of tannic acid on the activity of acrosin extracted from human and ram spermatozoa

\begin{tabular}{|c|c|c|c|c|}
\hline \multirow[b]{2}{*}{ 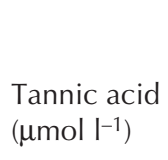 } & \multicolumn{2}{|c|}{ Human } & \multicolumn{2}{|c|}{ Ram } \\
\hline & $\begin{array}{l}\text { Residual activity } \\
(\%)\end{array}$ & $\begin{array}{c}\text { Acrosin } \\
\left(\mu \text { iu } 10^{-6} \text { spermatozoa) }\right.\end{array}$ & $\begin{array}{l}\text { Residual activity } \\
(\%)\end{array}$ & $\begin{array}{c}\text { Acrosin } \\
\left(\mu \mathrm{iu} 10^{-6} \text { spermatozoa }\right)\end{array}$ \\
\hline 0 & 100 & $79.46 \pm 5.21$ & 100 & $1139.00 \pm 58.18$ \\
\hline 50 & $76.80 \pm 4.38^{\mathrm{a}}$ & $60.91 \pm 3.45^{\mathrm{a}}$ & $80.00 \pm 5.00^{\mathrm{a}}$ & $911.20 \pm 56.95^{a}$ \\
\hline 75 & $68.60 \pm 2.51^{\mathrm{a}}$ & $54.51 \pm 1.99^{a}$ & $71.20 \pm 3.35^{\mathrm{a}}$ & $810.97 \pm 38.12^{\mathrm{a}}$ \\
\hline 100 & $61.20 \pm 3.03^{a}$ & $48.63 \pm 2.41^{\mathrm{a}}$ & $60.80 \pm 1.48^{\mathrm{a}}$ & $692.51 \pm 16.89^{a}$ \\
\hline 150 & $52.40 \pm 1.95^{\mathrm{a}}$ & $41.63 \pm 1.55^{\mathrm{a}}$ & $48.00 \pm 2.55^{\mathrm{a}}$ & $546.72 \pm 29.04^{a}$ \\
\hline 200 & $44.60 \pm 3.65^{\mathrm{a}}$ & $35.44 \pm 2.90^{\mathrm{a}}$ & $40.80 \pm 1.48^{a}$ & $462.72 \pm 16.89^{a}$ \\
\hline 250 & $38.60 \pm 2.30^{\mathrm{a}}$ & $30.67 \pm 1.83^{\mathrm{a}}$ & $34.00 \pm 2.92^{\mathrm{a}}$ & $387.26 \pm 33.21^{\mathrm{a}}$ \\
\hline 300 & $25.00 \pm 3.81^{\mathrm{a}}$ & $19.87 \pm 3.03^{\mathrm{a}}$ & $27.20 \pm 1.48^{\mathrm{a}}$ & $309.81 \pm 16.86^{\mathrm{a}}$ \\
\hline 400 & $8.80 \pm 2.17^{a}$ & $6.99 \pm 1.72^{\mathrm{a}}$ & $13.80 \pm 2.86^{\mathrm{a}}$ & $157.18 \pm 32.62^{a}$ \\
\hline
\end{tabular}

Values are mean $\pm \mathrm{SD}(n=5)$.

a Values with a superscript are significantly different from the control value in that column $(P \leqslant 0.02)$.

acid $\mathrm{I}^{-1}$. The $\mathrm{IC}_{50}$ for acrosin in human and ovine extracts was $150 \mu \mathrm{mol} \mathrm{I-1}$. Acrosin in human extracts $(79.46 \mu \mathrm{iu}$ $10^{-6}$ spermatozoa) and in ovine acrosomal extracts (1139 $\mu$ iu $10^{-6}$ spermatozoa) was inhibited almost completely by $400 \mu \mathrm{mol}$ tannic acid $\mathrm{I}^{-1}$ (Table 3 ).

\section{Effect of tannic acid on pure enzyme activity}

In additional experiments, plasmin (2 miu), t-PA (5 iu) and u-PA (50 miu) were added to solutions containing 0.25-200 $\mu \mathrm{mol}$ tannic acid $\mathrm{I}^{-1}$ ) and assayed for residual activity. The $\mathrm{IC}_{50}$ of all three enzymes was $1 \mu \mathrm{mol} \mathrm{I}^{-1}$. Plasmin activity was reduced by $92 \%$ at $200 \mu \mathrm{mol}$ tannic acid $\mathrm{I}^{-1}$, whereas t-PA and u-PA activator activities were reduced by 93 and 95\%, respectively, at $100 \mu \mathrm{mol}$ tannic acid $\mathrm{l}^{-1}$ (Table 4).

\section{Discussion}

Flavonoids are a group of naturally occurring low molecular weight benzo[r]pyrone derivatives that are ubiquitous in plants (Havsteen, 1983). Although their mechanism of action is not entirely clear, the flavonoids act as competitive enzyme inhibitors (Kuppusamy et al., 1990). Considering the numerous benzene rings and hydroxyl groups present in the structure of tannic acid, it is possible that the inhibitory effects of tannic acid may result from conformational changes or denaturation of the enzymes caused by hydrogen bonding or hydrophobic interactions between the enzymes and tannic acid.

The present data demonstrate clearly that tannic acid has potent inhibitory effects on acrosin activity and plasminogen activator activity in human and ovine acrosomal 
Table 4. Inhibitory effects of tannic acid on plasmin, tissue-type plasminogen activator and urokinase-type plasminogen activator activity in pure enzyme preparations

\begin{tabular}{|c|c|c|c|c|c|c|}
\hline \multirow{2}{*}{$\begin{array}{l}\text { Tannic } \\
\text { acid } \\
\left(\mu \mathrm{mol} \mathrm{I}{ }^{-1}\right)\end{array}$} & \multicolumn{2}{|c|}{ Plasmin } & \multicolumn{2}{|c|}{ Tissue-type plasminogen activator } & \multicolumn{2}{|c|}{ Urokinase-type plasminogen activator } \\
\hline & $\begin{array}{l}\text { Residual activity } \\
\qquad(\%)\end{array}$ & miu & $\begin{array}{l}\text { Residual activity } \\
(\%)\end{array}$ & iu & $\begin{array}{l}\text { Residual activity } \\
(\%)\end{array}$ & $\operatorname{miu}$ \\
\hline 0 & 100 & 2.00 & 100 & 5.00 & 100 & 50.00 \\
\hline 0.25 & $75.40 \pm 3.84^{\mathrm{a}}$ & $1.42 \pm 0.09^{a}$ & $80.60 \pm 6.31^{a}$ & $4.03 \pm 0.32^{\mathrm{a}}$ & $84.40 \pm 4.45^{\mathrm{a}}$ & $42.20 \pm 2.22^{\mathrm{a}}$ \\
\hline 0.50 & $58.80 \pm 4.76^{\mathrm{a}}$ & $1.18 \pm 0.10^{\mathrm{a}}$ & $65.20 \pm 5.81^{a}$ & $3.26 \pm 0.29^{a}$ & $60.00 \pm 7.21^{a}$ & $30.00 \pm 3.61^{a}$ \\
\hline 1.0 & $50.40 \pm 4.04^{\mathrm{a}}$ & $1.01 \pm 0.08^{\mathrm{a}}$ & $51.80 \pm 5.26^{\mathrm{a}}$ & $2.59 \pm 0.26^{\mathrm{a}}$ & $49.60 \pm 3.97^{a}$ & $24.80 \pm 1.99^{a}$ \\
\hline 5.0 & $42.20 \pm 4.14^{\mathrm{a}}$ & $0.84 \pm 0.08^{a}$ & $32.80 \pm 5.72^{\mathrm{a}}$ & $1.64 \pm 0.29^{a}$ & $41.60 \pm 3.43^{a}$ & $20.80 \pm 1.72^{a}$ \\
\hline 10.0 & $35.20 \pm 2.39^{a}$ & $0.70 \pm 0.05^{\mathrm{a}}$ & $20.60 \pm 7.54^{a}$ & $1.03 \pm 0.38^{\mathrm{a}}$ & $33.20 \pm 3.11^{\mathrm{a}}$ & $16.60 \pm 1.56^{a}$ \\
\hline 50.0 & $27.40 \pm 2.89^{a}$ & $0.55 \pm 0.06^{a}$ & $10.40 \pm 1.52^{\mathrm{a}}$ & $0.52 \pm 0.08^{a}$ & $16.60 \pm 4.34^{a}$ & $8.30 \pm 2.17^{a}$ \\
\hline 100.0 & $20.80 \pm 2.39^{a}$ & $0.42 \pm 0.05^{\mathrm{a}}$ & $6.80 \pm 1.79^{a}$ & $0.34 \pm 0.09^{a}$ & $4.60 \pm 1.14^{\mathrm{a}}$ & $2.30 \pm 0.57^{a}$ \\
\hline 200.0 & $7.80 \pm 1.48^{\mathrm{a}}$ & $0.16 \pm 0.03^{a}$ & - & - & - & - \\
\hline
\end{tabular}

-: total inhibition.

Values are mean $\pm \mathrm{SD}(n=5)$.

a Values with a superscript are significantly different from the control value within that column $(P \leqslant 0.02)$.

extracts. The inhibition is concentration-dependent. This is believed to be the first report of tannic acid-induced inhibition of these acrosomal enzymes and provides a new explanation for flavonoid-induced male infertility.

Newly ovulated mammalian ova are embedded in a mass of the cumulus oophorus, corona and zona pellucida. Spermatozoa must pass through these barriers at the time of fertilization. The acrosome contains several hydrolytic enzymes that are necessary for penetration of the spermatozoon through these investments (Yanagimachi, 1994). The involvement of proteinases at different stages of fertilization seems increasingly likely as the molecular events of fertilization are progressively being elucidated.

It is generally accepted that the activity of acrosin, a unique serine proteinase associated with the acrosome of mammalian spermatozoa, is essential for fertilization (Meizel, 1984; Katz et al., 1987; De Jonge et al., 1989; Schill, 1991). The essential role of acrosin in fertilization is indicated by the ability of various proteinase inhibitors to block fertilization or to impair sperm functions involved in fertilization (Saling, 1981; Dravland and Meizel, 1982; Van der Ven et al., 1985; De Jonge et al., 1989).

In addition to acrosin, the well-characterized gamete proteinases, plasminogen activators, are likely candidates for catalysing proteolysis during fertilization. The membrane localization of plasminogen activators in spermatozoa and the release of plasminogen activators during acrosome reaction indicate that these proteolytic enzymes could participate in fertilization (Smokovitis et al., 1992a; Taitzoglou et al., 1996). Plasmin, the active enzyme of the plasminogen activation system, is also a trypsin-like proteinase that can cleave and degrade a wide spectrum of substrates (Danø et al., 1985). Indeed, previous results indicated that in vitro fertilization of mouse eggs was in- hibited by antibodies that inhibit the catalytic activity of plasmin and that addition of plasminogen to the fertilization medium increased the yield of fertilized eggs (Huarte et al., 1993).

The primary mechanism for the contraceptive effect of flavonoids appears to be inhibition of several acrosomal enzymes (Yuan et al., 1995; Taitzoglou et al., 1999). Some flavonoids inhibit the activity of hyaluronidase from bovine testes (Kuppusamy et al., 1990), as well as from snake, scorpion and bee venom (Kuppusamy and Das, 1991). Recently, Li et al. (1997) demonstrated that tannic acid inhibited the activity of hyaluronidase extracted from monkey spermatozoa in a concentration-dependent manner over the range $50-200 \mu \mathrm{mol} \mathrm{I}{ }^{-1}$.

Sperm motility and high velocity are important for sperm binding to and penetration into the zona pellucida; immotile spermatozoa cannot bind to or penetrate through the zona pellucida (Liu and Baker, 1993; Yanagimachi, 1994). Many of the common polyphenolic compounds that are naturally present in abundance in plant extracts exert inhibitory effects on mammalian sperm motility in vitro. These polyphenolic compounds could be another cause of the antifertility effects of crude plant extracts; it is possible that augmentation of the generation of superoxide radicals by polyphenols may inhibit sperm motility in vitro (Kumar et al., 1989). Indeed, co-incubation of monkey spermatozoa with tannic acid significantly inhibited percentage motility (Li et al., 1997). In contrast, in the present study the percentage motility of ram spermatozoa was reduced significantly only at the highest concentration tested. This discrepancy may be attributable to species differences. In addition, plasmin added to bovine semen affected sperm motility; the highest increase in sperm motility was observed after addition of $5 \mathrm{ng}$ plasmin $\mathrm{ml}^{-1}$ (Smokovitis et al., 1987). 
In the present study, tannic acid inhibited plasminogen activator activity in pure enzymatic preparations with $\mathrm{IC}_{50}$ of $1 \mu \mathrm{mol} \mathrm{I-1}$ for plasmin, t-PA and u-PA. In acrosomal extracts, the $\mathrm{IC}_{50}$ of tannic acid was $100 \mu \mathrm{mol} \mathrm{I-1}$ for human spermatozoa and $200 \mu \mathrm{mol} \mathrm{I}^{-1}$ for ram spermatozoa. As tannic acid inhibits a large number of enzymes, the discrepancy observed between pure preparations and acrosomal extracts might be due to the fact that tannic acid affects other sperm factors beside the plasminogen activator and plasmin systems when mixed with acrosomal extracts.

Two-step Ficoll separation was necessary during isolation of human spermatozoa for the acrosin assay as simple Ficoll separation did not remove acrosin inhibitors completely. This finding was in accordance with those of Breden et al. (1996).

As sperm acrosin does have a role in multiple phases of mammalian fertilization and plasminogen activators and the plasmin system are involved in several stages of fertilization, flavonoids such as tannic acid will be useful tools for assessing the involvement of acrosomal enzymes in these gamete functions.

\section{References}

Biggers JD, Whitten WK and Whittingham DG (1971) The culture of mouse embryos in vitro. In Methods in Mammalian Embryology pp 86-116 Ed. JC Daniel, Jr. WH Freeman and Co., San Francisco

Bravo L (1998) Polyphenols: chemistry, dietary sources, metabolism and nutritional significance Nutrition Reviews 56 317-333

Breden TG, Berg R and Plotka ED (1996) Effects of substrate and separation method on acrosin amidase measurements Journal of Andrology 17 443-448

Chung KT, Wong TY, Wei Cl, Huang YW and Lin Y (1998) Tannins and human health: a review Critical Reviews in Food Science and Nutrition 38 421-464

Danø K, Andreasen PA, Grøndahl-Hansen J, Kristensen P, Nielsen LS and Skriver L (1985) Plasminogen activators, tissue degradation, and cancer Advances in Cancer Research 44 139-266

De Jonge CJ, Mack SR and Zaneveld LJD (1989) Inhibition of the human sperm acrosome reaction by proteinase inhibitors Gamete Research 23 387-397

Deutch DG and Mertz ET (1970) Plasminogen purification from human plasma by affinity chromatography Science 170 1095-1096

Dravland JE and Meizel S (1982) The effect of inhibitors of trypsin and phospholipase A2 on the penetration of zona pellucida-free hamster eggs by acrosome-reacted hamster sperm Journal of Andrology 3 $338-344$

Havsteen B (1983) Flavonoids, a class of natural products of high pharmacological potency Biochemical Pharmacology 32 1141-1148

Hertog MG, Hollman PC, Katan MB and Kromhout D (1993) Intake of potentially anticarcinogenic flavonoids and their determinants in adults in The Netherlands Nutrition and Cancer 20 21-29

Huarte J, Vassali J-D, Belin D and Sakkas D (1993) Involvement of the plasminogen activator/plasmin proteolytic cascade in fertilization Developmental Biology 157 539-546

Jones R (1991) Interaction of zona pellucida glycoproteins, sulphated carbohydrates and synthetic polymers with proacrosin, the putative egg-binding protein from mammalian spermatozoa Development 111 1155-1163

Katz DF, Drobnis EZ, Cherr GN, Baltz J, Yudin AI, Cone RA and Cheng LY (1987) The biophysics of sperm penetration of the cumulus and zona pellucida. In The New Horizons in Sperm Research pp 275-285 Ed. H Mohri. Japanese Scientific Society Press, Tokyo
Kennedy WP, Van der Ven HH, Straus JW, Bhattacharyya AK, Waller DP, Zaneveld LJD and Polakoski KL (1983) Gossypol inhibition of acrosin and proacrosin, and oocyte penetration by human spermatozoa Biology of Reproduction 29 999-1009

Kennedy WP, Kaminsky JM, Van der Ven HH, Jeyendran RS, Reid DS, Blackwell J, Bielfeld P and Zaneveld LJD (1989) A simple clinical assay to evaluate the acrosin activity of human spermatozoa Journal of Andrology 10 221-231

Kumar P, Laloraya M and Laloraya MM (1989) The effect of some polyphenolic compounds on sperm motility in vitro: a structure-activity relationship Contraception 39 531-539

Kuppusamy UR and Das NP (1991) Inhibition effects of flavonoids on several venom hyaluronidases Experientia 47 1196-1200

Kuppusamy UR, Khoo HE and Das NP (1990) Structure activity studies of inhibitors of hyaluronidase Biochemical Pharmacology 40 397-401

Li M-W, Yudin AI, VandeVoort CA, Sabeur K, Primakoff P and Overstreet JW (1997) Inhibition of monkey sperm hyaluronidase activity and heterologous cumulus penetration by flavonoids Biology of Reproduction 56 1383-1389

Liu DY and Baker HWG (1993) Inhibition of acrosin activity with a trypsin inhibitor blocks human sperm penetration of the zona pellucida Biology of Reproduction 48 340-348

Lui CW and Meizel S (1979) Further evidence in support of a role for hamster hydrolytic enzymes in the acrosome reaction Journal of Experimental Zoology 207 173-186

Mack SR and Zaneveld LJD (1987) Acrosomal enzymes and ultrastructure of unfrozen and cryotreated human spermatozoa Gamete Research 18 375-383

Meizel S (1984) The importance of hydrolytic enzymes to an exocytotic event, the mammalian sperm acrosome reaction Biological Reviews $\mathbf{5 9}$ $125-157$

Paganga G and Rice-Evans CA (1997) The identification of flavonoids as glycosides in human plasma FEBS Letters $\mathbf{4 0 1} 78-82$

Rekkas C, Belibasaki S, Taitzoglou I, Kokolis N and Smokovitis A (1991) Increased plasminogen activator activity and plasminogen activator inhibition in spermatozoa and seminal plasma of the ram after serum gonadotrophin (PMSG) administration. Correlation with the increased level of testosterone in the blood Andrologia 23 273-278

Rekkas C, Kokolis N and Smokovitis A (1993) Breed and seasonal variation of plasminogen activator activity and plasminogen activator inhibition in spermatozoa and seminal plasma of the ram in correlation with testosterone in the blood Andrologia 25 101-109

Saling PM (1981) Involvement of trypsin-like activity in binding of mouse spermatozoa to zonae pellucidae Proceedings National Academy of Sciences USA 78 6231-6235

Schill WB (1991) Some disturbances of acrosomal development and function in human spermatozoa Human Reproduction 6 969-978

Shi QX and Friend DS (1985) Effect of gossypol acetate on guinea pig epididymal spermatozoa in vivo and their susceptibility to capacitation in vitro. Journal of Andrology 6 45-52

Smokovitis A, Kokolis N, Alexopoulos C, Alexaki E and Eleftheriou E (1987) Plasminogen activator activity, plasminogen activator inhibition and plasmin inhibition in spermatozoa and seminal plasma of man and various animal species. Effect of plasmin on sperm motility Fibrinolysis 1 253-257

Smokovitis A, Kokolis N, Taitzoglou I and Rekkas C (1992a) Plasminogen activator: the identification of an additional proteinase at the outer acrosomal membrane of human and boar spermatozoa International Journal of Fertility 37 308-314

Smokovitis A, Rekkas C, Vainas E, Kokolis N and Taitzoglou I (1992b) The effect of chromosomal anomalies on the plasminogen activator activity, plasminogen activator inhibition and plasmin inhibition in spermatozoa and seminal plasma. I. Chromosomal chimaerism XX/XY in the ram Animal Reproduction Science 29 241-254

Srivastava A, Gupta G and Setty BS (1989) Studies on mechanism(s) of antifertility action of gossypol in rat and hamster Contraception 39 337-355

Srivastava PN (1973) Removal of acrosomes of ram and rabbit spermatozoa Journal of Reproduction and Fertility 33 323-326 
Srivastava PN, Munell JF, Yang CH and Foley CW (1974) Sequential release of acrosomal membranes and acrosomal enzymes of ram spermatozoa Journal of Reproduction and Fertility 36 363-372

Taitzoglou I, Kokolis N and Smokovitis A (1996) Release of plasminogen activator and plasminogen activator inhibitor from spermatozoa of man, bull, ram and boar during acrosome reaction Molecular Andrology $\mathbf{8}$ 187-197

Taitzoglou IA, Tsantarliotou M, Kouretas D and Kokolis NA (1999) Gossypol-induced inhibition of plasminogen activator activity in human and ovine acrosomal extract Andrologia 6 355-359

Tesarik J, Drahorad J and Peknicova J (1988) Subcellular immunochemical localization to acrosin in human spermatozoa during the acrosome reaction and zona pellucida penetration Fertility and Sterility 50 133-141

Tsantarliotou M (1997) The Effect of Glucocorticoids and Melatonin on the Activity of Specialized Proteases in Spermatozoa and Seminal Plasma of the Ram PhD Thesis, Aristotle University of Thessaloniki, Greece

Urch UA and Patel H (1991) The interaction of boar sperm proacrosin with its natural substrate, the zona pellucida, and with polysulfated polysaccharides Development 111 1165-1172

Van der Ven HH, Kaminski J, Bauer L and Zaneveld LJD (1985) Inhibition of human sperm penetration into zona-free hamster oocytes by proteinase inhibitors Fertility and Sterility 43 609-619

World Health Organization (1992) Laboratory Manual for the Examination of Human Semen and Semen-Cervical Mucus Interaction Cambridge University Press, Cambridge

Yanagimachi R (1994) Mammalian fertilization. In The Physiology of Reproduction pp 189-317 Eds E Knobil and JD Neill. Raven Press, New York

Yuan YY, Shi QX and Srivastava PN (1995) Inhibition of rabbit sperm acrosomal enzymes by gossypol Molecular Reproduction and Development 40 228-232

Received 22 February 2000.

Accepted 7 August 2000. 